\title{
Managing family businesses in light of methodological assumptions for higher education
}

\author{
Mariola Dźwigoł-Barosz, ${ }^{1 *}$ and Henryk Dźwigoł ${ }^{2}$ \\ ${ }^{1}$ Silesian University of Technology, Faculty of Organisation and Management, ul. Roosevelta 26, 41- \\ 800 Zabrze, Poland \\ ${ }^{2}$ Silesian University of Technology, Faculty of Organisation and Management, ul. Roosevelta 26, 41- \\ 800 Zabrze, Poland
}

\begin{abstract}
Family businesses play a key role in the Polish economy, accounting for approx. $36 \%$ of the MMSP sector. Development of family companies is connected with dilemmas regarding, among others, continuity and succession. In Polish business, a long-awaited moment of handing over the power and ownership to the next generation has appeared - the so-called generation of millennials, which is currently being educated at universities. The aim of this study is to identify areas of cooperation between universities and family businesses in the context of preparing potential successors to manage Polish family businesses at the dawn of the fourth industrial revolution. The article presents differences in the perception of the role of education in the succession process by successors and doyens of Silesian family enterprises on the basis of the author's own research. An attempt was made here to explain the divergence of opinions between the successors from the millennials generation and the representatives of the baby boomer generation (doyens). The main part of the study consists of a proposal of areas of academic education for future managers of family businesses under the conditions of Industry 4.0, including the use of educational methods adapted not only to requirements of the market, but also expectations of the millennials generation.
\end{abstract}

\section{Introduction}

Family companies are becoming an increasingly important element of the Polish economy. It is estimated that there are almost 2 million entities of this kind in Poland. In the European Union, family companies constitute about $60 \%$ of all operating enterprises [1] and are the most natural form of entrepreneurship, being, at the same time, the engine for development of each economy. They form the most numerous group of companies in Poland and may become the basis of permanent economic growth [2].

Development of family enterprises is connected with dilemmas concerning, among others, continuity and succession. The long-awaited moment of handing over power and

\footnotetext{
* Corresponding author: mariola.dzwigol-barosz@polsl.pl
} 
ownership to the next generation - the so-called millennials, who nowadays seek an education at universities in order to start a career on the job market - has appeared in Polish business.

It can be seen that a need for education in the field of family entrepreneurship in the broadest sense has been created. Both public and private education have noticed a niche for educating family entrepreneurs and to a greater or lesser extent are trying to fill it.

In Polish reality, there is a lack of an educational offer aimed at educating future managers of family enterprises, which may put Polish family businesses in a worse situation than their counterparts in countries where succession processes and their social awareness are much more advanced.

At the same time, one of the main challenges currently faced by family businesses is the rapid changes and the need for professionalisation, which forces them to function in the era of Industry 4.0 while sustaining the advantages provided by a well-understood family business. It is a necessary condition for them to develop effectively, to compete on the market, to be an attractive business partner and employer.

The aim of this article is to indicate potential areas of cooperation between universities and family businesses, mainly in the field of educational offerings for future successors in the field of the unique specificity of running a family business at the dawn of the fourth industrial revolution. The proposal of cooperation areas is to ultimately indicate the direction for educating the generation of millennials in order to increase the succession potential among heirs of family businesses, taking into account the use of didactic methods adapted not only to requirements of the market, but also expectations of the generation of successors, including the concept of Industry 4.0.

\section{Differences in perception of the role of education in the succession process by successors and doyens of Silesian family businesses}

In the research conducted by the author [3], 11 factors determining the succession process were subjected to the assessment of successors and doyens.

By comparing in pairs (using the U-Mann-Whitney test) the significance of differences between the averages of individual factors, groups of factors were formed for which the differences are statistically insignificant. In this way a ranking of factors, determining a good succession process for successors and doyens was obtained. The form of the ranking is presented in Table 1.

Table 1. Ranking of factors determining a succession process

\begin{tabular}{|c|c|c|c|}
\hline $\begin{array}{c}\text { Ranking } \\
\text { position }\end{array}$ & $\begin{array}{c}\text { Factors determining a good } \\
\text { succession process according to } \\
\text { successors }\end{array}$ & $\begin{array}{c}\text { Ranking } \\
\text { position }\end{array}$ & $\begin{array}{c}\text { Factors determining a good } \\
\text { succession process according to } \\
\text { doyens }\end{array}$ \\
\hline 1 & confidence in the successor & 1 & education \\
\hline 2 & good relations with parents & 2 & confidence in the successor \\
\hline 3 & good relations with clients & 3 & $\begin{array}{c}\text { confidence in the successor's } \\
\text { abilities }\end{array}$ \\
\hline 5 & $\begin{array}{c}\text { confidence in the successor's } \\
\text { abilities }\end{array}$ & 4 & $\begin{array}{c}\text { good relations with parents } \\
\text { good relations between the } \\
\text { successor and other family } \\
\text { members }\end{array}$ \\
\hline 6 & $\begin{array}{c}\text { good relations between the successor } \\
\text { and other family members }\end{array}$ & 5 & good relations with clients \\
\hline
\end{tabular}


Continued table 1

\begin{tabular}{|c|c|c|c|}
\hline 7 & education & 7 & knowledge of the business /market \\
\hline 8 & $\begin{array}{l}\text { good relations between the } \\
\text { successor and employees }\end{array}$ & 8 & experience in the business \\
\hline 9 & $\begin{array}{l}\text { the successor's interest in the } \\
\text { business }\end{array}$ & 9 & $\begin{array}{l}\text { good relations between the successor and } \\
\text { employees }\end{array}$ \\
\hline 10 & knowledge of the business /market & 10 & clear criteria for distribution of assets \\
\hline 11 & experience in the business & $*$ & $\begin{array}{l}\text { the successor's interest in the business * (not } \\
\text { included in the ranking due to a lack of } \\
\text { compatibility of the doyen's assessments) }\end{array}$ \\
\hline
\end{tabular}

Source: authors' own research

Analysing the research results obtained, it can be noted that the factor of the highest importance according to the doyens presents itself quite surprisingly. In this case, the researched indicated the key role of education in the examined process, where the successors ranked it only seventh place.

So, why such a discrepancy between the opinions of the successors and doyens on the role of education in the succession process?

The reason for this can be found in the generation gap of family businesses between parents from the 'Baby Boomers' generation and children from the 'Millennials'generation (Figure 1).

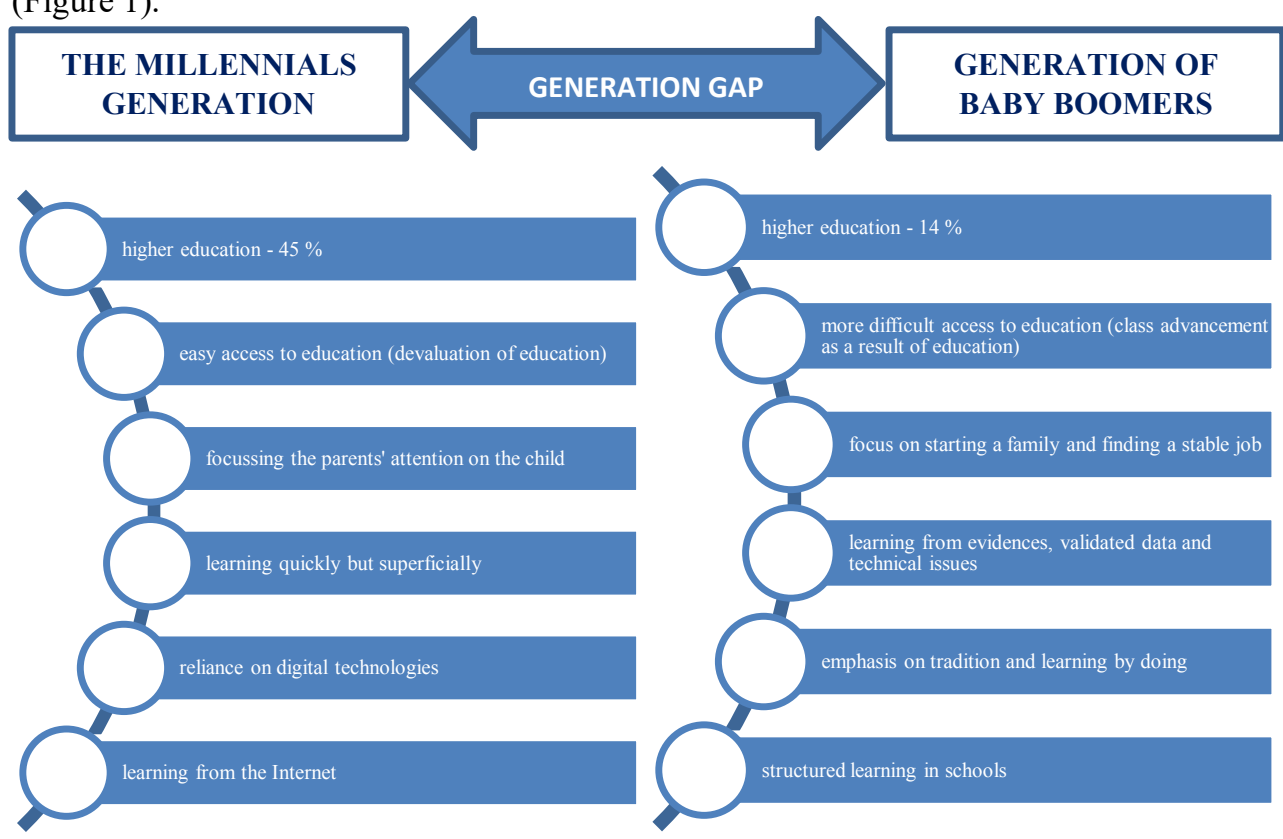

Fig. 1. Generation gap between Baby Boomers and Millennials. Source: authors' own research

Successive generations are increasingly better educated - the level of education is definitely higher for millennials (generation $\mathrm{Y}$ ) than for X, and even more so for baby boomers $(B B)$. The proportion of people with higher education is increasing in the following generations: $14 \%-\mathrm{BB}, 27 \%-\mathrm{X}$ and $45 \%-$ Y. Baby boomers, on the other hand, are distinguished by a higher share of people with primary or lower education than for other generations [4].

The approach to the role of education of the baby boomers' representatives is in line with G.S. Becker's theory of human capital [5], which assumes that every person is equipped by nature, upbringing and education with specific qualifications, which increase with the 
increase of investment in formal education. The higher the level of education, the greater the professional skills and earning potential [6]. It should be noted here that opportunities of the baby boomers generation to gain university education were definitely more limited, as they were conditioned to a large extent by the process of functioning in the society, where the main goal was to start a family and find a stable job.

Generally, people from the baby boomers generation rate their competences as the lowest compared to the other generations, while the highest rating is usually recorded for representatives of generation Y [4].

On the other hand, when describing the Millennials (Y) generation, one may encounter certain opposing characteristics, which are a consequence of the conditions in which they were brought up, among others due to easy access to education and parents' focus on the child [7]. In Poland, the doctrine that assumed the state remunerates a university which acquires a student has changed. Owners of high school diplomas became a deficit product for which universities had to fight. Thus, the centre of gravity in the negotiations between university and student changed. In the past, the bargaining power was held by university, behind which stood the tradition and power of issuing a diploma, after the paradigm shift - by the student, who brought money to the university [8].

Nevertheless, people belonging to Generation $\mathrm{Y}$ are well educated and aware of their competences, acquired and shaped not only through formal schooling, but above all by the use of the virtual digital world [9].

In the author's research, the low position of education in the succession process in the ranking of successors may also be due to the fact that Millennials successors rely very much on digital technologies [10]. They learn quickly, albeit superficially. They do not pursue indepth analysis of issues when they know that they can quickly find answers to their questions by 'asking' them on the Internet ultimately, they are willing to look at studies, summaries, scripts, lists and tables made by someone else [11]. The young successor generation may therefore assume that instead of acquiring in-depth academic knowledge, all they need is that which is available with less effort and in less time.

Millennials are the most diverse generation ever, navigating complex software with ease, performing tasks while listening to music and while talking on a cell phone. On the other hand, employers report that they are severely lacking in basic skills, the ability to think critically or to take initiative $[12,13]$.

\section{Potential areas of cooperation between universities and Polish family businesses}

Managing a family enterprise requires a different perspective on the realised functions of present-day managers and successors. It brings with it the necessity of developing new educational models at business departments of universities, which will take education of narrower groups of specialised managers into account to a greater extent.

As J. Tapies and J. Ward point out, if succession is not caused by an unexpected tragic event, it should be gradual. The future successor should be provided with adequate education and experience [14].

At the same time, future family business leaders need to be aware of changes occurring in an organisation's surroundings at the dawn of the fourth industrial revolution. Taking full advantage of business environments may mean investing in appropriate technologies, entering into further relationships, partnerships and alliances to ensure growth, and introducing new products or services to maintain leadership or implementing innovations to reduce the risk of obsolescence [15].

Family businesses are often perceived as not very innovative. However, recent research shows that these entities are some of the most trend-setting organisations in their markets, 
often introducing ideas at a faster pace than businesses of other types [16, 17]. It is the role of next-generation leaders to continue these efforts and expand digital technology into all areas of family business activities. The Deloitte report [15] shows that it is the new generations that are most aware of importance of digitalisation (as many as $45 \%$ of them believe that their awareness in this area is high).

Therefore, it is crucial for successors to know how digitalisation can affect the business model of an enterprise that they will manage in the era of Industry 4.0 and how its strategy and activities should be changed.

It turns out that roughly a quarter of leaders in the new generation of family businesses have already adopted a strategy to use digital technologies, but nearly $40 \%$ do not have a digital strategy, or claim that they are still working on it [15].

The research results of the report cited above confirm the necessity of developing an educational offer for future successors of family businesses that takes into account the dynamics and development of the business environment, in which new technologies affect not only the financial and economic objectives of family businesses, but also help to maintain control and autonomy in the surrounding economic space.

The process of preparing successors to manage family businesses in the conditions of Industry 4.0 is a challenge for universities, as it requires the development of programmes that not only provide substantive knowledge in the field of economics, management, law, or new technologies, but also succession itself, which is an extremely 'sensitive' process.

The proposal of cooperation between higher education institutions and Polish family enterprises refers mainly to development of a specialisation within business departments that take the education programme of future successors into consideration, indicating the didactic framework concerning family entrepreneurship in the era of the fourth industrial revolution. It indicates areas for acquiring knowledge and skills useful in the succession process with particular consideration of such aspects as succession of power and succession of ownership in a family enterprise.

The education programme for future managers of family enterprises consists of 6 modules focused mainly on: specificity and complexity of the succession process; information policy in this process; management of the successors' managerial competences with special emphasis on their improvement; organisational culture of the family enterprise and formal and legal conditions of succession and management of the family enterprise in the era of Industry 4.0 (Figure 2).

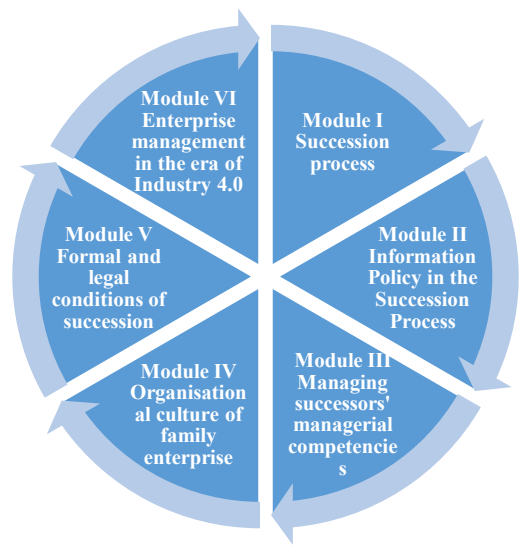

Fig. 2. Six-module successor education programme. Source: author's own research

The thematic outline in terms of individual modules is shown in Table 2. 
Table 2. Scope of the six-module programme for successor education in the era of the fourth industrial revolution

\begin{tabular}{|c|c|}
\hline \multirow[t]{2}{*}{ MODULE I } & SUCCESSION PROCESS \\
\hline & $\begin{array}{l}\text { - importance of the succession process in a family enterprise, } \\
\text { - barriers to successful succession, } \\
\text { - } \text { analysis and assessment of threats and risks resulting from handing over the } \\
\text { business to a successor, } \\
\text { formulation of important requirements needed for selection of a potential } \\
\text { successor, } \\
\text { selection of probable successors according to specific criteria (e.g., } \\
\text { education, experience, abilities), } \\
\text { - compement of a special programme for development of successor } \\
\text { - choosing the moment of succession, } \\
\text { - communication of the decision, } \\
\text { - creation of company strategy in the period after succession, } \\
\text { - countering the credibility gap after the transfer of power and ownership, } \\
\text { defining the role of the outgoing leader after the succession and organising } \\
\text { and planning alternative activities for the doyens. }\end{array}$ \\
\hline \multirow{2}{*}{ MODULE II } & INFORMATION POLICY IN THE SUCCESSION PROCESS \\
\hline & $\begin{array}{l}\text { - who is to be informed and when to inform them about the process of } \\
\text { succession (paying attention to the specific nature of HR processes in a } \\
\text { family enterprise and the consequences of decisions taken in this field, } \\
\text { which may be connected with a decrease in motivation or even with the } \\
\text { departure of employees from the company), } \\
\text { rules for preparation of a communication plan in succession (what should a } \\
\text { succession plan contain, who should prepare it and who should accept and } \\
\text { approve it), } \\
\text { - } \text { principles of effective communication in the context of succession, } \\
\text { - getting feedback, } \\
\text { communication styles used in various situations (acquiring the ability to } \\
\text { adapt one's message depending on interlocutor and situation), } \\
\text { preparing the declaration of a successor (when starting the succession } \\
\text { process and informing employees of the fact in due time, defining own } \\
\text { goals and those on the level of company and team). }\end{array}$ \\
\hline \multirow[t]{2}{*}{ MODULE III } & MANAGING SUCCESSOR'S MANAGERIAL COMPETENCIES \\
\hline & $\begin{array}{l}\text { - qualifications related to family business sector, } \\
\text { - } \quad \text { reading into practice the rules of social co-existence on equal terms, } \\
\text { activities, } \\
\text { - } \text { a set of experiences built up in the family-owned company in different } \\
\text { working positions, } \\
\text { - } \text { business experience, } \\
\text { - ability to create something new, } \\
\text { ability to express one's shoughts clearly and in a way comprehensible to } \\
\text { - an interlocutor, } \\
\text { - ability to cope with organising one's own and other people's activities, } \\
\text { - of ractical ability to assess market opportunities and threats in the context } \\
\text { - using creativity to turn opportunities into new ideas and putting them into } \\
\text { practice, } \\
\text { ability to meticulously analyse phenomena, draw conclusions and put } \\
\text { them into practice, }\end{array}$ \\
\hline
\end{tabular}




\begin{tabular}{|c|c|}
\hline & $\begin{array}{l}\text { - openness to change and seeking opportunities, } \\
\text { - } \quad \text { ambition, willingness to stand out and to achieve success, } \\
\text { - defending one' s own rights (challenges). }\end{array}$ \\
\hline \multirow[t]{2}{*}{ MODULE IV } & ORGANISATIONAL CULTURE OF FAMILY ENTERPRISE \\
\hline & $\begin{array}{l}\text { - cultural values of family businesses with an emphasis on meeting the needs } \\
\text { of the founding family, which is non-official and not reflected in the } \\
\text { mission or strategy, } \\
\text { balancing between family interests and business development interests in } \\
\text { the enterprise, } \\
\text { - social norms of family organisations, } \\
\text { modes of communication, stories, narratives, myths and metaphors that } \\
\text { reflect the family power structure and importance of the family structure } \\
\text { within its enterprise, } \\
\text { organisational stereotypes of family businesses, which sanction the greater } \\
\text { commitment, loyalty and diligence of family members compared to other } \\
\text { employees, } \\
\text { family customs, mores and rituals, which are associated with blurring the } \\
\text { boundaries of official organisations with the life of founding family, } \\
\text { the key role of business founders as leaders, being current managers who } \\
\text { belong to the founding family, } \\
\text { the division between family subculture and beyond-family subculture, } \\
\text { which differ considerably from each other, }\end{array}$ \\
\hline \multirow[t]{2}{*}{ MODULE V } & $\begin{array}{l}\text { FORMAL AND LEGAL CONDITIONS OF SUCCESSION } \\
\end{array}$ \\
\hline & $\begin{array}{l}\text { Provisions on inheritance law, contained in the civil code, the commercial } \\
\text { companies code and other laws, in particular: } \\
\text { - Act of } 5 \text { July } 2018 \text { on Succession Management of a natural person's } \\
\text { enterprise, Journal of Laws of } 2018 \text {, item } 1629-\text { the Act regulates the } \\
\text { rules of temporary management of an enterprise after the death of an } \\
\text { entrepreneur who in his own name performed business activity on the } \\
\text { basis of his entry in the Central Register of Business Activity Information, } \\
\text { hereinafter referred to as the 'CEIDG', and to continue economic } \\
\text { activities carried out by means of the said enterprise. } \\
\text { The Act of } 23 \text { April } 1964 \text {. Civil Code (consolidated text of Journal of } \\
\text { Laws of } 2016 \text {, item } 380 \text { as amended). The Act regulates the rules of } \\
\text { inheritance of a share or shares in a limited liability company. Shares in a } \\
\text { limited liability company can be inherited through a testamentary bequest } \\
\text { or through statutory inheritance. } \\
\text { The Code of Commercial Partnerships and Companies - Article } 187 \S 1 \\
\text { 'Upon the transfer of a share, a part thereof or a fractional part thereof to } \\
\text { another person, and upon establishing a pledge or usufruct of the share, } \\
\text { the interested parties shall notify the company, providing evidence of the } \\
\text { transfer or establishing the pledge or usufruct'. } \\
\text { Articles of association of a limited liability company may regulate } \\
\text { whether an heir may enter the company in place of a deceased partner - } \\
\text { continuity of a company's governing bodies is an important element of its } \\
\text { operation, which is why it is worthwhile to include, when drafting the } \\
\text { articles of association, important elements that will prevent legal problems } \\
\text { in the event of death of one of the partners. It is therefore worth thinking } \\
\text { through the provisions so that in the event of such a difficult situation the } \\
\text { company and its activity is not undermined and does not lead to its } \\
\text { bankruptcy. }\end{array}$ \\
\hline \multirow[t]{2}{*}{ MODULE VI } & ENTERPRISE MANAGEMENT IN THE ERA OF INDUSTRY 4.0 \\
\hline & - $\quad$ Assumptions of the Industry 4.0 concept. \\
\hline
\end{tabular}




\begin{tabular}{|c|c|}
\hline & 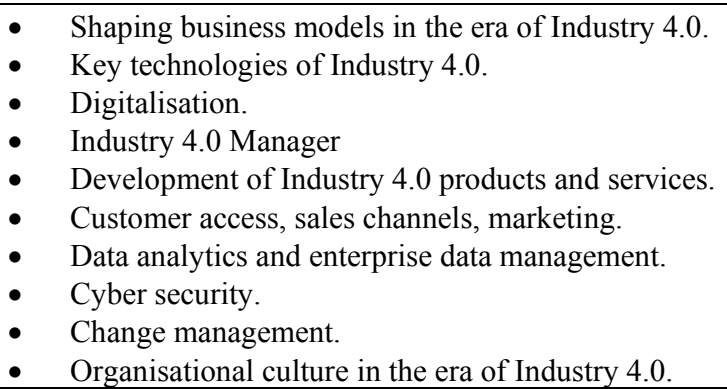 \\
\hline
\end{tabular}

Source: author's own research

The proposed six-module programme of education in the era of the fourth industrial revolution, addressed to the successors of family companies, may constitute an answer to the need of professionalisation and the necessity of raising competences of future management staff - especially in the face of dynamic market changes and generational succession. The combination of tradition and modernity becomes the greatest challenge for successors, who must learn how to cope in a dynamically changing environment, preserving at the same time their identity and the coherence typical of family enterprises.

\section{Teaching methods in the process of educating successors of the millennial generation}

Children from family businesses account for approx. $30 \%$ of all students in general. This is a huge human capital that will soon feed into the labour market [18].

Representatives of the Millennial generation expect technology to play a large role in the learning process, enabling access to vast information sources and providing knowledge through multimedia with an emphasis on entertainment during the learning process $[19,20$, 21]. This is a generation shaped by other conditions, expecting an educational offer which takes this fact into account. It is necessary to provide them with modern study programmes, which will be implemented in a way that allows access to modern technologies, takes into account the objectives which students set for themselves during their studies and provides them with the basis for acquiring competences which are useful in the current labour market [11].

The six-module education programme for future family business managers proposed by the author, in addition to aspects related to succession, business management in specific family conditions and in the conditions of the fourth industrial revolution, should also take the expectations of successors from the Next Generation into account, bearing in mind that 'the young are not enemies of teaching, they just think it can be done in a better way' [22].

In view of the above, effective academic education of the new generation requires the adaptation of teaching methods to a new audience, including, in addition to traditional teaching methods, conducting classes in the style of practical workshops and learning through experience (individual modules should be conducted by an expert-practitioner in a given field and/or a coach/business coach).

A diversified approach to education of future successors is also confirmed by the author's research [3], the aim of which was to select methods of improving competences by means of which it will be possible to eliminate diagnosed competence gaps in potential successors of family enterprises. In this research, experts were asked to assign a value on a scale of 1 to 3 to each method of competence improvement, where: 1 - low effectiveness of the method for bridging the competence gap within a given competence group, 2 - average effectiveness of the method for bridging the competence gap within a given competence group, 3 - high low 
effectiveness of the method for bridging the competence gap within a given competence group.

It was assumed that the most effective method of improving a given competence is the one which was most often indicated by experts as the most effective. For the purpose of this study, partial raw results of the conducted research are presented in Table 3.

Table 3. The most effective methods for bridging selected competence gaps

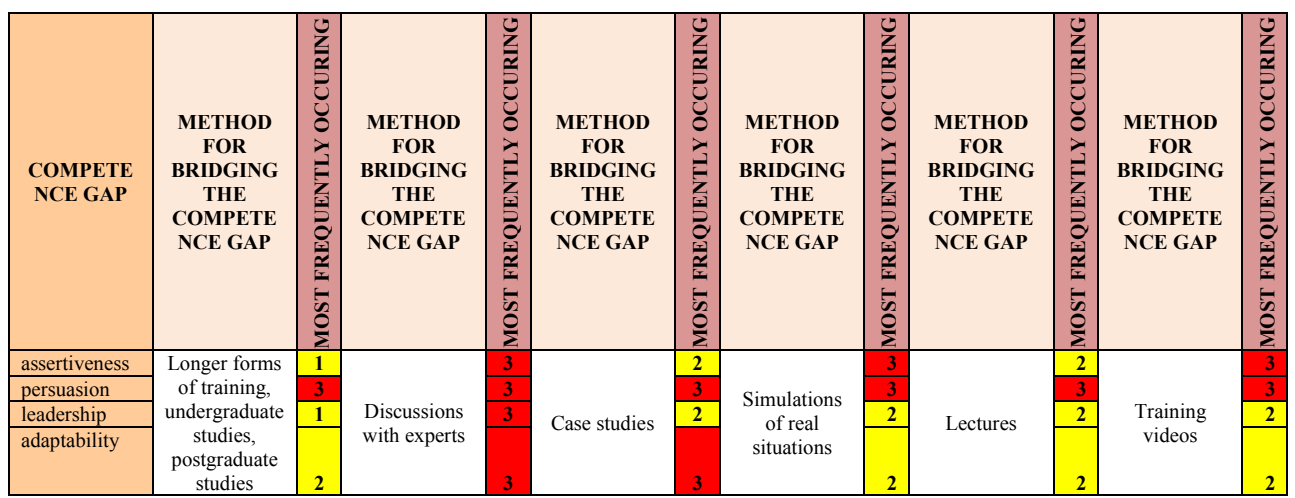

Source: author's own research

The obtained research results allow us to state that discussions with experts were used as a method of bridging all selected competence gaps of successors. Therefore, this method may constitute an optimal method in the process of improving competences in the area of assertiveness, persuasion, leadership and adaptability.

Simulations of real-life situations and training videos were evaluated by experts as methods with high effectiveness in bridging the gap within the groups of competences in the field of assertiveness and persuasion, and medium effectiveness in the case of leadership and adaptability.

Case studies work best, in the opinion of experts, for bridging competence gaps in persuasion and adaptability and on average for assertiveness and leadership.

Longer forms of training, undergraduate and postgraduate studies, and lectures, which are the most traditional educational method most often used in academic education, scored best in the process of bridging competence gaps in the area of persuasion.

Against the background of all presented methods of improving successors' competences, the method with the worst results is: longer forms of training, undergraduate and postgraduate studies, giving grounds for the necessity to develop an attractive academic education offer for future successors, taking the specificity of both family entrepreneurship and the concept of Industry 4.0 into account. This means that it is crucial to be able to adjust educational methods to heterogeneous audiences (people belonging to different generations), taking also the possibility of remote learning into account [23] with the use of IT infrastructure and software, allowing synchronous and asynchronous interaction between students and academic teachers. Technology can be used to help Millennials develop essential soft skills. Research conducted by W.G. Bowen, M.M. Chingos, K.A. Lack and T.I. Nygren [24] confirm that online learning through remote education platforms is as effective as traditional face-to-face methods. According to the authors, this is an encouraging prospect for universities due to the fact that the demand for online classes is increasing.

\section{Summary}

Successors of family businesses will determine the strength of the Polish economy at the moment of entering the job market. Analysis of the choice of fields of study made by potential 
inheritors of family businesses, which oscillate to a large extent around fields of study related to running a company and business, allows us to state that the young generation of successors wants to prepare themselves in the best possible way for running a company in the future. High awareness of successors regarding the 'family character' of businesses run by their parents gives rise to hope that the knowledge acquired by them during their studies will be used in the next generations of Polish family business owners, increasing thereby percentage of successful intra-family successions [25].

Ensuring that a family business is multi-generational, grows and remains highly efficient is dependent to a large extent on an appropriate competence potential of successors. When preparing an educational offer for successors of the millennial generation, it should be borne in mind that they will be managing family businesses under conditions of profound changes caused by the development of digital technologies, which result in deep digitisation of the value chain, business models and products and services. The Fourth Industrial Revolution is affecting transformations across entire area of a company's operations, so it is not enough to make only technological changes, but it is necessary to implement a well-prepared digitalisation strategy. The key element of the transformation process is the leader who manages this change while understanding both the opportunities and benefits offered by Industry 4.0, but who also knows the specifics and the realities of his company. Therefore, the programme of educating successors in the era of the fourth industrial revolution should be based on the experience and knowledge of experts - practitioners, with an orientation towards the realisation of classes in the form of workshops, with use of the latest case studies, with support by such methods as simulations of real situations and training films, with simultaneous use of multimedia technologies.

The biggest challenge facing universities is to tailor an educational offer aimed at millennials that takes training of soft skills into account in a highly technological environment [26]. A creative approach to using educational innovations to improve future learning and a deep verification of teaching methods to meet the requirements of Education 4.0 is therefore necessary $[27,28]$.

The proposed six-module programme for educating successors of Polish family enterprises indicates a didactic framework, giving examples of areas of cooperation with universities within the scope of family entrepreneurship while taking enterprise management in the era of the fourth industrial revolution into consideration, and has been developed for leaders of digital transformation in Polish family enterprises. Thanks to such a programme it will be possible not only to acquire the desired successor competences but also to effectively implement the Industry 4.0 concept.

\section{References}

1. Informacja o wynikach kontroli Najwyższej Izby Kontroli, Bariery prawne w rozwoju firm rodzinnych w Polsce, https://www.nik.gov.pl/plik/id,19747,vp,22361.pdf (2018)

2. Lewandowska, E. Więcek-Janka, A. Hadryś-Nowak, M. Wojewoda, Model 5 poziomów definicyjnych firm rodzinnych. Podstawy metodyczne i wyniki badań firm rodzinnych w Polsce, Poznań, 2016, http://www.europeanfamilybusinesses.eu/uploads/Modules/Publications/poland-fambus.pdf (2016)

3. M. Dźwigoł-Barosz, PWN, Warszawa (2017)

4. J. Wiktorowicz, I. Warwas, M. Kuba, E. Staszewska, P. Woszczyk, A. Stankiewicz, J. Kliombka-Jarzyna, Wolters Kluwer, Warszawa (2019)

5. G.S. Becker, University of Chicago Press, Chicago (1964) 
6. K. Cichy, K. Malaga, Kapitał ludzki w modelach i teorii wzrostu gospodarczego, in M. Herbst (ed.), Kapitał ludzki i kapitał społeczny a rozwój regionalny, Scholar, Warszawa, 22-23 (2007)

7. Smolbik-Jęczmień, Modern Management Review, XVIII, 20(4) (2013)

8. J. Rojewski, Czy wyższe wykształcenie i dyplom magistra są już zbędne?, Rzeczpospolita, https://www.rp.pl/Spoleczenstwo/305039980-Czy-wyzszewyksztalcenie-i-dyplom-magistra-sa-juz-zbedne.html, 06 maja 2018 (2018)

9. M. Wawer, Edukacja - Technika - Informatyka, 4/1 (2013)

10. R. Huntley, Allen and Unwin, Crows Nest, Australia (2006).

11. D. Ciechanowska, Akademickie kształcenie pokolenia $\mathrm{Y}$ w perspektywie zmian w dydaktyce szkoły wyższej, in D. Ciechanowska (ed.), Perspektywy zmian w praktyce ksztatcenia akademickiego, Szczecin (2014)

12. J.W. Lowery, The millennials come to campus: John Wesley Lowery talks with William Strauss. About Campus, 6-12 (July-August 2001)

13. G. Marx, Preparing students and schools for a radically different future. USA Today (2002)

14. J. Tapies, J.L. Ward, Family Values and Value creation, Palgrave Macmillan, New York, 14 (2008)

15. Raport Centrum Firm Rodzinnych Deloitte, Nowe pokolenie firm rodzinnych. Eksploracja środowisk biznesowych, 7, 14-15 (2018)

16. Deloitte, Next-generation family businesses: Evolution keeping family values alive (2016)

17. P. Duran et al., Academy of Management Journal, 59(4) (2016)

18. Raport: Barometr sukcesyjny - ścieżki kariery pokolenia Next Generation w polskich firmach rodzinnych, Instytut Biznesu Rodzinnego, Poznań, 8 (2017)

19. R.S. Franz, Journal of Management Education, 22(1) (1998)

20. S.F. Gardner, American Journal of Pharmaceutical Education, 70(4) (2006)

21. J. Chelliah, Clarke, E. On the Horizon, 19(4) (2011)

22. L. Gratton, The Three Paradoxes Of Generation Y, http://www.forbes.com/sites/lyndagratton/2013/06/06/the-three-paradoxes-ofgeneration-y/, 6 czerwca 2013 (2013)

23. Dziennik Ustaw Rzeczpospolitej Polskiej Poz. 1861, Rozporządzenie Ministra Nauki i Szkolnictwa Wyższego z dnia 27 września 2018 r. w sprawie studiów, rozdział 5 (2018)

24. W.G. Bowen, M.M. Chingos, K.A. Lack, T.I. Nygren, Journal of Policy Analysis and Management, 33(1) (2013)

25. J. Klimek, Raport: Barometr sukcesyjny - ścieżki kariery pokolenia Next Generation w polskich firmach rodzinnych, Instytut Biznesu Rodzinnego, Poznań, 14 (2017)

26. L.A. Gibson, W.A. Sodeman, Organization Development Journal, (2014)

27. A.A. Shahroom, N. Hussin, International Journal of Academic Research in Business \& Social Sciences, 8(9) (2018)

28. S. Nimon, Journal of Institutional Research, 13(1) (2007) 